\title{
COMPANY PERFORMANCE APPRAISAL USING THE BALANCE SCORECARD METHOD TO IMPROVE PERFORMANCE IN PUBLIC COMPANIES JASA TIRTA I
}

\author{
Supriyadi Eko Prasetiyo, Mohammad Burhan, Gaguk Apriyanto \\ Postgraduate School of Merdeka University of Malang \\ Email: eljie111@gmail.com
}

\begin{abstract}
Jasa Tirta I Public Company is a state-owned company engaged in the management of water resources. The quality of the performance of an organization can be known by measuring the performance of the achievement of performance indicators. Comprehensive planning of performance indicators is needed. This study aims to determine the performance measurement of Perum Jasa Tirta I by the Balanced Scorecard method and then analyzed by the PDCGA (Plan-Do-Check-Goal-Action) method for continuous improvement to improve company performance. The research method used in this study uses a mixed-method approach. The results showed that the measurement of public performance based on the Balanced Scorecard Perum Jasa Tirta I 2015-2019 method is divided into 4 approaches: financial perspective, customer perspective, internal business process perspective, and learning \& growth perspective including good performance. Judging from the financial perspective it is included in the very good category. From the customer perspective, it is included in the excellent category. From the internal business perspective it is classified as quite good, Electricity Raw Water Service indicators reached $93 \%$ of the 100\% target and environmental management achieved $97 \%$ of the $100 \%$ target. From the perspective of learning \& growth in the excellent category.
\end{abstract}

\section{Keywords: Balanced Scorecard, Performance Measurement}

\begin{abstract}
ABSTRAK
Perum Jasa Tirta I adalah BUMN yang bergerak dibidang pengelolaan sumber daya air. Kualitas kinerja sebuah organisasi dapat diketahui dengan pengukuran kinerja atas pencapaian indikator kinerja. Diperlukan perencanaan indikator kinerja yang komprehensif. Penelitian ini bertujuan untuk mengetahui pengukuran kinerja Perum Jasa Tirta I dengan metode Balanced Scorecard kemudian dianalisis dengan metode PDCGA (Plan-Do-Check-Goal-Action) untuk continuous improvement dalam rangka meningkatkan kinerja perusahaan. Metode penelitian yang digunakan dalam penelitian ini menggunakan pendekatan mixed metode. Hasil penelitian menunjukkan bahwa pengukuran kinerja publik berdasarkan metode Balanced Scorecard Perum Jasa Tirta I 2015-2019 terbagi menjadi 4 pendekatan : perspektif keuangan, perspektif pelanggan, perspektif proses bisnis internal dan perspektif pembelajaran \& pertumbuhan termasuk dalam kinerja yang baik. Dilihat dari prespektif keuangan masuk dalam kategori sangat baik. Dari perpektif pelanggan masuk dalam kategori sangat baik. Dari perpektif bisnis internal masuk dalam kategori cukup baik, indikator Layanan Air Baku Listrik tercapai 93\% dari target 100\% dan pengelolaan lingkungan tercapai $97 \%$ dari target $100 \%$. Dari perspektif pembelajaran \& pertumbuhan dalam kategori sangat baik.
\end{abstract}

Kata kunci: Balanced Scorecard, Pengukuran Kinerja 


\section{INTRODUCTION}

Performance measurement is important for the company. In this increasingly competitive business world, the challenges faced by both profit-oriented and non-profit organizations are becoming increasingly complex. With these challenges, companies are required to be more professional in managing their business and continue to strive to formulate and perfect their business strategies to win the competition. The balanced scorecard can be applied to business organizations that produce products or services. However, assessing the company's performance solely from a financial standpoint can be misleading, because good financial performance can be achieved at the expense of the company's longterm interests.

Norton and Kaplan introduced the balanced scorecard as a refinement of the scorecard (performance recording card) that has been used by many people who generally only pay attention to the financial aspect. Robert Kaplan sharpens the concept of performance measurement by determining an effective, balanced approach to measuring the performance of a company's strategy. The approach is based on 4 perspectives, namely: finance, customers, internal business processes, learning, and growth.

According to research by (Rumintjap, 2013) Balanced Scorecard approach, top management translates their strategies into performance measures that can be understood and can be done by employees. Thus, the Balanced Scorecard is a management performance measurement system that is derived from vision and strategy and reflects the most important aspects of a business. Based on experience in companies that implement the Balanced Scorecard, it is known that there is an improvement in the company's performance from year to year. This is because all employees in the company clearly understand that the activities they do affect the success of achieving the company's vision and mission and strategy

Jasa Tirta 1 Public Corporation (Perum) is a State-Owned Enterprise (BUMN) in the form of a public company whose entire ownership is $100 \%$ owned by the Government of Indonesia. Perum Jasa Tirta 1 is engaged in the field of water resources management. Its working area includes the Brantas River, Bengawan Solo, Jratun Seluna, Serayu Bogowonto, and Asahan River, as well as Dams in the watershed. As a
State-Owned Enterprise, Perum Jasa Tirta I has a commercial and social mission that must be carried out by a State Company. On the one hand, as a company that is demanded to maximize profits Perum Jasa Tirta $I$ is still burdened with social missions, including not only irritating people's rice fields irrigation but also controlling floods, maintaining water availability, and also to conduct environmental management that can cause losses to Perum Jasa Tirta I (Profil Perum Jasa Tirta I, 2020).

Financial performance appraisal is considered a paradigm that must be changed by overall performance appraisal, one of which is a balanced scorecard analysis which can also be a strategic management tool for the company. For this reason, this research is deemed necessary to be carried out as one of the strategic efforts to improve the company's performance towards even better.

\section{LITERATURE REVIEW}

\section{Performance Measurement}

According to (Rudianto, 2013): Performance is a picture of achieving the implementation of an activity or program in realizing the organization's vision, mission, goals, and objectives. Simply stated, performance is "work performance". Performance can also be interpreted as "the work" of a person or group of people in an organization.

Meanwhile according to (Harmono, 2011) Company performance is generally measured based on net income (earnings) or some other basis such as investment returns (return on investment) and earnings per share (earnings per share). The elements that are directly related to the measurement of net income (profit) are income and expenses

In general, the basic concept of evaluating company performance refers to the final results of the management process about the organization's ability to achieve its objectives by using the company's economic resources efficiently and effectively. Wider company performance measurement with the concept of the Balanced Scorecard, where this idea is to balance financial aspects with non-financial aspects in evaluating company performance (Apriyanto \& Firdiansjah, 2017)

\section{Balance Scorecard}

The definition of the Balanced Scorecard in a nutshell is a strategic management system 
to measure the performance as a whole from the financial \& non-financial aspects; communicating the vision, strategy, and targets to stakeholders; managing strategy implementation (Kaplan, 2010).

Meanwhile, according to (Fahmi, 2010), the Balanced Scorecard is a concept that aims to support the realization of the company's vision, mission, and strategy with long-term targets that emphasize on four studies, namely the perspective of finance, customers, internal business processes, and learning and growth.

Assessment in the Balanced Scorecard method is divided into 4 perspectives namely financial perspective, internal business, customers, growth, and learning.

Financial Perspective

(Financial Perspective) measures the company's financial goals to create shareholder value that is sustainable and supports sub-goals in terms of revenue growth, productivity, and risk management. The purpose of this perspective is to answer "how should the organization be accountable to shareholders?" (Kaplan, 2010).

Customer Perspective (Customer Perspective) measures the achievement of customer desires, reflected in aspects of satisfying customers, customer mastery, and retain customers. The purpose of this perspective is to answer "how should the organization be accountable to Customers / Stakeholders?" (Kaplan, 2010).

Internal Business Processes (Internal Business Processes Perspective) measure organizational performance in terms of the effectiveness and efficiency of processes in internal procedures. The purpose of this perspective is to answer "what business processes must be carried out by the organization?" (Kaplan, 2010).

Learning \& Growth Perspective (Learning $\&$ Growth Perspective) measures organizational growth to achieve employee development, information systems, and strategy alignment. The purpose of this perspective is to answer "how will the organization maintain its ability to change and develop?" (Kaplan, 2010).

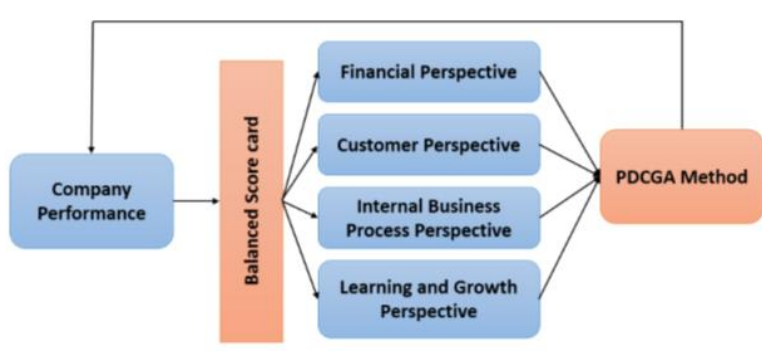

Figure 1. Research Analysis Model

\section{RESEARCH METHOD}

\section{Research design}

This research uses a mixed-methods approach. As for conducting research using research steps by combining two approaches, namely a qualitative approach and a quantitative approach. This study tries to analyze and describe the analysis of company performance appraisal using the Balanced Scorecard method to improve performance at Tirta I Public Corporation.

\section{Data collection technique}

There are two data collection methods in this study, namely:

a. Field Research, which is a collection that is collecting primary and secondary data by coming directly to Perum Jasa Tirta I then do:

1) Interview, by asking directly the leadership and employees of Perum Jasa Tirta I related to the collection of data needed in this research.

2) Observation, namely by making direct observations of the research object which is the source of the data obtained is truly objective.

b. Library (Library Research), namely by studying books and writings related to the problem to be discussed, as well as searching for documents that support research.

\section{Data analysis technique}

To get the conclusions from this research, an analysis pf each Balanced Scorecard perspective is performed as folows :

a. Financial Perspective

1) Current Ratio $=$ Current Assets Current Liabilities

2) The Ratio = of Own Capitals to Total Assets $=$ own Capital 
3) Return On Assets = Profit after tax

Total Assets

b. Customer Perspective

1) Number of Complain $=$ EComplain ¿Customer

2) Number of Complain $=$ $\frac{\text { Sold Customer }}{\text { LCustomer }}$

c. Internal Business Perspective

1) Electric Raw Water Service = Realization

Target

2) PDAM and Industry Raw Water Service Realization Target

3) Environmental Management = Realization Target

d. Learning and Growth

1) Employee Retention = Number of Outgoing Employees Number of Employees

2) Employee Training Performance = Number of Training Participants Number of Training Hours

3) Employee Productivity = Operating Profit

After doing a performance evaluation based on the Balanced Scorecard method, make improvements to the deficiencies in measuring performance by following per under the scope of the company, and analyze differences in the results of performance measurements for continuous improvement.

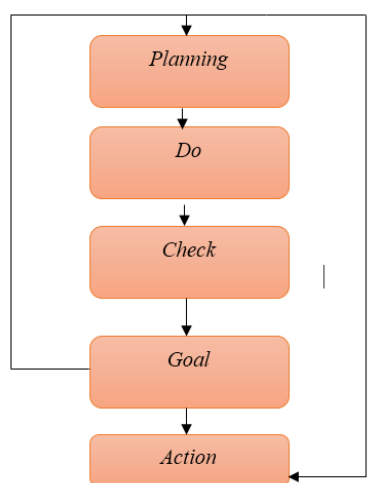

Figure 2. PDCGA Cycle (Plan - Do - Check Goal - Action)

Source: Vasovsk and Weinsten - ESD 60 Lean / six Sigma system, LFM, MIT 2004 in (Gunawan \& Nandika, 2018)

\section{RESULTS AND DISCUSSION}

By following per under the analysis of each perspective for measuring the performance of Perum Jasa Tirta I with the Balanced Scorecard, the following results are obtained:

Table 1. Summary of Performance of Tirta I Public Corporation 2015-2019

\begin{tabular}{|l|l|l|l|l|l|l|}
\hline \multirow{2}{*}{ Indicator } & \multicolumn{5}{|c|}{ Year } & \multirow{2}{*}{ Average } \\
\cline { 2 - 6 } & $\mathbf{2 0 1 5}$ & $\mathbf{2 0 1 6}$ & $\mathbf{2 0 1 7}$ & $\mathbf{2 0 1 8}$ & $\mathbf{2 0 1 9}$ & \\
\hline $\begin{array}{l}\text { Current ratio } \\
\text { Ratio of equity } \\
\text { capital to } \\
\text { assets }\end{array}$ & $589 \%$ & $409 \%$ & $383 \%$ & $407 \%$ & $419 \%$ & $442 \%$ \\
\hline $\begin{array}{l}\text { Return on } \\
\text { assets }\end{array}$ & $85 \%$ & $81 \%$ & $82 \%$ & $82 \%$ & $84 \%$ & $83 \%$ \\
\hline $\begin{array}{l}\text { Customer } \\
\text { Retention }\end{array}$ & $16 \%$ & $19 \%$ & $16 \%$ & $13 \%$ & $12 \%$ & $15 \%$ \\
\hline $\begin{array}{l}\text { Number of } \\
\text { Complain }\end{array}$ & $1 \%$ & $2 \%$ & $5 \%$ & $1 \%$ & $1 \%$ & $2 \%$ \\
\hline $\begin{array}{l}\text { Electricity } \\
\text { Raw Water } \\
\text { Services }\end{array}$ & $78 \%$ & $94 \%$ & $97 \%$ & $80 \%$ & $116 \%$ & $93 \%$ \\
\hline $\begin{array}{l}\text { PDAM } \\
\text { Industry Raw } \\
\begin{array}{l}\text { Water } \\
\text { Services }\end{array}\end{array}$ & $78 \%$ & $121 \%$ & $98 \%$ & $100 \%$ & $101 \%$ & $100 \%$ \\
\hline $\begin{array}{l}\text { Environmental } \\
\text { Management }\end{array}$ & $108 \%$ & $116 \%$ & $101 \%$ & $107 \%$ & $52 \%$ & $97 \%$ \\
\hline $\begin{array}{l}\text { Employee } \\
\text { Retention }\end{array}$ & $0,7 \%$ & $0,5 \%$ & $1,0 \%$ & $0,5 \%$ & $0,0 \%$ & $0,5 \%$ \\
\hline $\begin{array}{l}\text { Training } \\
\text { Performance }\end{array}$ & $96 \%$ & $130 \%$ & $151 \%$ & $132 \%$ & $105 \%$ & $123 \%$ \\
\hline $\begin{array}{l}\text { Employee } \\
\text { Productivity }\end{array}$ & $114 \%$ & $126 \%$ & $148 \%$ & $123 \%$ & $129 \%$ & $128 \%$ \\
\hline
\end{tabular}

Based on the calculation of Balance Scorecard Perum Jasa Tirta I in 2015-2019 which is divided into 4 perspectives namely, financial perspective, customer perspective, internal business perspective, and learning and learning perspective as a whole including in performance. 
Table 2. Balanced Scorecard Analysis using PDCGA for Continuation Improvement

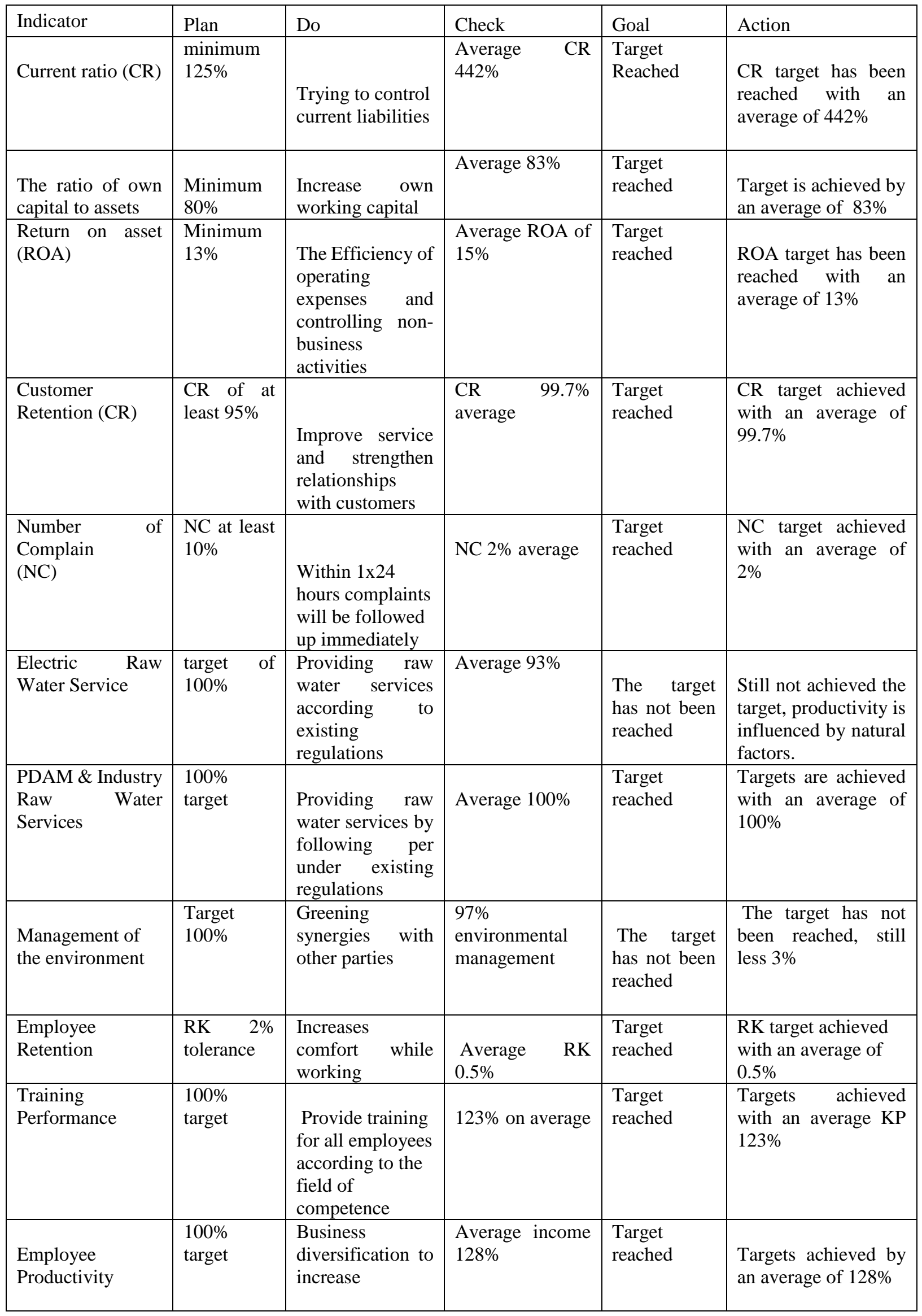


Based on the calculation of Balance Scorecard Perum Jasa Tirta I in 2015-2019 which is divided into 4 perspectives namely, financial perspective, customer perspective, internal business perspective, and learning and learning perspective as a whole including in performance.

First, the financial perspective in measuring performance can be seen from 3 indicators namely, Current Ratio, Own Capital Ratio to Assets, and Return on Assets. Advanced strategies that can be used include companies that can review how the implementation and implementation of the strategies carried out so far. Whether the strategy has been effective or not to be applied further. An effective strategy should be able to achieve the goals set, so that the company does not have to make further investments except to maintain and repair facilities, not to expand or build a new capability.

Second, the customer perspective in measuring performance can be seen from 2 indicators namely, Customer Retention and Number of Complain. Strategies that can be done by Perum Jasa Tirta I improve good relations with customers to increase loyalty by holding gatherings or joint social activities and also making special applications for customer containers need to submit complaints and criticisms and direct complaints so that problems are handled more quickly.

Third, the internal business perspective in conducting performance measurements can be seen from 3 indicators namely, electricity raw water service, PDAM raw water service and industry, and environmental management. One effort that can be done by Perum Jasa Tirta I is to maintain internal business improvement including further coordination with customers with their respective performance targets. Regarding environmental management, it is necessary to have innovations for greening facilities, so that these activities do not wait for the rainy season.

Fourth, the Learning and growth perspective in measuring performance can be seen from 3 indicators namely employee retention, training performance, and employee productivity. by paying attention to employee satisfaction. Employees who are satisfied with the company will certainly be more productive at work. Conversely, employees who are not satisfied with the company will also reduce work productivity. When employees are not productive, of course, it will affect the company, because their duties and responsibilities cannot be carried out to the maximum. In addition to employee satisfaction that needs attention is increasing comfort and growing a sense of belonging to the company.

\section{CONCLUSIONS AND RECOMMENDATIONS}

\section{Conclusions}

Based on the results of the analysis, the company performance appraisal with the Balanced Scorecard method to improve performance at the Tirta I Public Corporation (Perum) can be concluded as follows:

\section{a. Financial Perspective}

Measured using 3 indicators namely Current Ratio, Ratio of total own capital to assets, and Return on Assets. Based on the financial perspective in measuring the performance of Perum Jasa Tirta I, it can be said to be very good because of the three indicators all reached the target.

b. Customer Perspective

Measured using 2 indicators namely Customer Retention and Number of Complain. Based on the customer's perspective in measuring the performance of Perum Jasa Tirta I, it can be said to be very good because the two indicators have reached the specified target.

c. Internal business perspective Measured using 3 indicators namely Electric Raw Water Service, PDAM Raw Water Service, and Industrial and Environmental Management. Based on the perspective of the Internal Business Process in measuring the performance of Perum Jasa Tirta I, it can be said that it is quite good from the three indicators, two indicators have not achieved the targets, namely Electric Raw Water Service, Electric Raw Water Service 93\% and Environmental Management achieved $97 \%$ on average.

\section{d. On the Learning and Growth Perspective}

Measured using 3 indicators namely employee retention, training performance, and employee productivity. Based on the Learning and Growth perspective in measuring the 
performance of Perum Jasa Tirta I can be said to be very good from the three indicators.

\section{Recommendations}

a. Conduct continuous evaluation and monitoring, both in the long and short term as well as monitoring the implementation of work programs, as well as long-term which leads to the influence of environmental changes on the vision, mission, and strategies used by the company.

b. Regarding the achievement of performance, it is expected that the company will socialize to all elements of the employee regarding the targets and work plans of the company so that all employees can support to achieve the specified targets.

\section{REFERENCES}

Apriyanto, G., \& Firdiansjah, A. (2017). Rekonstruksi Model Penilaian Kinerja Dana Pensiun Dengan Modified Baldrige Assessment Sebagai Upaya Menuju Good Pension Fund Governance. Universitas Merdeka Malang.
Fahmi, I. (2010). Manjemen Kinerja. Alfabeta.

Gunawan, \& Nandika, F. P. (2018). Penilaian Kinerja Perusahaan Dengan Balanced Scorecard Dalam Rangka Continuous Improvement (Studi Kasus Di Pt. Creative Mega Network Internasional Indonesia). Universitas Merdeka Malang.

Harmono. (2011). Manajemen Keuangan Berbasis Balance Scorecard Pendekatan Teori, Kasus dan Riset Bisnis. Bumi Aksara.

Kaplan, R. S. (2010). Conceptual Foundations of the Balanced Scorecard. Harvard Business School Accounting \& Management Unit, 10-74.

Profil Perum Jasa Tirta I. (2020). www.jasatirta1.co.id/id/ID/profil/

Rudianto. (2013). Akuntansi Manajemen: Informasi Untuk Pengambilan Keputusan Strategis. Erlangga.

Rumintjap, M. L. (2013). Penerapan balanced scorecard sebagai tolak ukur pengukuran kinerja di RSUD Noongan. Jurnal EMBA: Jurnal Riset Ekonomi, Manajemen, Bisnis Dan Akuntansi. 